\section{Michigan Technological

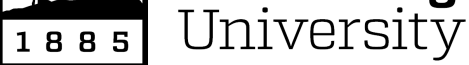

Michigan Technological University Digital Commons @ Michigan Tech

$1-21-2014$

\title{
Securitization of Residential Solar Photovoltaic Assets: Costs, Risks and Uncertainty
}

Theresa Alafita

Michigan Technological University

Joshua M. Pearce

Michigan Technological University

Follow this and additional works at: https://digitalcommons.mtu.edu/materials_fp

\section{Recommended Citation}

Alafita, T., \& Pearce, Joshua M. (2014). Securitization of residential solar photovoltaic assets: Costs, risks and uncertainty. Energy Policy, 67, 488-498. http://digitalcommons.mtu.edu/materials_fp/23 


\title{
Securitization of Residential Solar Photovoltaic Assets: Costs, Risks and Uncertainty
}

\author{
T. Alafita ${ }^{1}$ and J. M. Pearce ${ }^{1,2,3^{*}}$
}

1. Michigan Tech Open Sustainability Technology Laboratory, Michigan

Technological University, Houghton, MI 49931

2. Department of Materials Science \& Engineering, Michigan Technological University, Houghton, MI 49931

3. Department of Electrical \& Computer Engineering Michigan

Technological University, Houghton, MI 49931

* Corresponding author: 601 M\&M Building, 1400 Townsend Drive, Houghton, MI 49931-1295, ph:906-487-1466 email:pearce@mtu.edu

\begin{abstract}
:
Limited access to low-cost financing is an impediment to high-velocity technological diffusion and high grid penetration of solar photovoltaic (PV) technology. Securitization of solar assets provides a potential solution to this problem. This paper assesses the viability of solar asset-backed securities (ABS) as a lower cost financing mechanism and identifies policies that could facilitate implementation of securitization. First, traditional solar financing is examined to provide a baseline for cost comparisons. Next, the securitization process is modeled. The model enables identification of several junctures at which risk, and uncertainty influences costs. Next, parameter values are assigned and used to generate cost estimates. Results show that, under reasonable assumptions, securitization of solar power purchase agreements (PPA) can significantly reduce project financing costs, suggesting securitization is a viable mechanism for improving the financing of PV projects. The clear impediment to the successful launch of a solar ABS is measuring and understanding the riskiness of underlying assets. This study identifies three classes of policy intervention that lower the cost of ABS by reducing risk or by improving the measurement of risk: i) standardization of contracts and the contracting process, ii) improved access to contract and equipment performance data, and iii) geographic diversification.
\end{abstract}

Keywords: photovoltaic; renewable energy financing; securitization

\section{Introduction}

Over the last decade the solar photovoltaic industry (PV) has grown rapidly, gaining momentum from plummeting module costs, public interest in sustainable energy, and favorable policy support (Branker and Pearce, 2010; BNEF, 2012; IREC, 2012; SEIA, 2011). Taken together, in 2013 these factors propelled the US to become one of only four nations to surpass 10 GW of installed PV capacity, 83\% of which was installed after 2010 (Solar Industry, 2013). Given PV's ability to produce energy inexpensively, reliably, and sustainably (Pearce, 2002; Prindle et al., 2007; Timilsina et al., 2012; Branker, et al., 2011a), high levels of demand for new PV projects are expected to continue. However, there are significant capital requirements for transforming demand into installed PV capacity. For example, installation of 
3.3 GW of solar capacity in 2012 cost $\$ 12$ billion (Barbose et al., 2013). If market growth is to continue, solar developers require access to adequate financial capital. This capital is not available through the traditional tax equity market. Faced with both impending reductions in federal tax support and stricter capital requirements on banks, solar developers are looking for alternatives.

Solar asset-backed securities (ABS) are being explored as a promising option (Bolinger et al., 2009; Bolinger, 2009; Wilkins, 2002; Pietruszko, 2006; Branker et al., 2011b). By delivering access to the more than $\$ 100$ trillion pool of wealth managed by institutional and other investors, solar ABS has the potential to lower financing costs, and expand access to funding (Mendelsohn, 2013; UPI, 2011). This could be particularly beneficial to the development of smaller scale solar projects, where the funding environment is particularly challenging (Miller, 2012).

Though securitization has enabled other asset classes to successfully attract financial capital, there are several challenges impeding its widespread utilization by the solar industry (Herndon, 2012; Trabish, 2012). To facilitate the introduction of this new asset class, policymakers must understand the risks associated with different aspects of the asset, and look for ways to mitigate these risks. This paper focuses on three points at which risk and uncertainty affect the securitization process: 1 ) in the formation of the asset pool where there is uncertainty over off-taker behavior, 2) in the process of asset evaluation, and 3) in the purchase of the asset by uncertain investors.

By incorporating each of these well-known uncertainties in a simple model, the paper is able to evaluate their impacts on the cost of financing, and on the ability to raise capital through securitization. The model focuses on the securitization of solar PPAs, using parameterization to assess the importance of changes in key variables. A range of conditions under which ABS can successfully reduce costs is also identified using the cost of traditional solar financing as an upper bound. This information is useful in evaluating the benefit of different efforts to promote solar ABS.

There are many ongoing efforts to enact or create policies that will generate the conditions necessary for successful deployment of solar ABS. These policies are reviewed, and assessed according to their targeted point of impact. This allows interpretation of their potential influence on the cost of raising capital through securitization. With the information gleaned from the model, guidance is developed to target policies that play a significant role in determining the viability of securitization for the PV industry.

\section{Background}

\subsection{Traditional PV Finance}

Since passage of the Energy Policy Act of 2005 the federal government has used tax benefits to promote the solar power industry. While the benefits are generous, equaling between $50 \%$ and $60 \%$ of a solar project's 
installed cost (Bolinger et al., 2009a) much of this does not accrue to the solar developer. Solar development firms are typically small and possess little tax liability. They are unable to directly capture the value of federal support and instead exchange tax benefits for funding in the tax-equity finance market.

This type of financing is expensive, limited in supply and restricts a firm's ability to incorporate other forms of financing. In recent years, use of a third-party to monetize tax benefits, has resulted in borrowing costs of 12 20 percent depending on leverage (Minzt, 2010; Sanders et al., 2013; US PREF, 2011). Despite these high rates of return, the supply of tax-equity financing is very limited. With fewer than 20 U.S. taxable entities (primarily large investment banks, commercial banks, and insurance companies) actively participating in the tax-equity market (BNEF, 2012), only \$3 - \$6 billion of funding has been available for the entire renewable energy sector annually (Mendelsohn and Harper, 2012). For firms using tax equity financing, incorporation of cost reducing project level debt is very difficult as it increases risk for equity financiers (Mendelsohn, et al., 2012). These problems have motivated firms to seek alternate forms of financing.

\subsection{Solar Asset-Backed Securities}

Progress is being made towards the creation of a large and efficient solar ABS market that could supply adequate capital to the PV market. In 2013, leasing specialist SolarCity raised \$54 million with their solar ABS issuance (Parkinson, 2013). While this is a significant step in the maturation of solar financing, it is quite small in size relative to the $\$ 800$ million average value of ABS issued in other asset classes (Mendelsohn, 2012). Replication and expansion of SolarCity's success depends on improving efficiency and performance during each stage of the securitization process. Many policies have been suggested in pursuit of this goal.

By considering the point at which these policy efforts impact the process, it is possible to evaluate their potential role in the success of securitization. Formation of the asset pool is the first point of intervention considered. Decisions in the process of screening consumers, writing contracts and pooling assets determines the quality of the asset pool as measured by the rate of early contract termination. To understand how the rate of early contract termination influences the success of securitization, the process is modeled. The estimated cost of increases in the default rate can provide guidance for policy intervention and developer action. Asset evaluation by a rating agency is the next point of potential intervention. Raters must assess an assets' risk, but have limited data with which to make their assessments. The degree to which their estimates are erroneous influences the success of the securitization. Separating rater error from the contract default rate allows for particular attention to the benefit of policies focused on the rating process. Finally, the point at which the investor purchases the solar ABS is considered. Rates of return reflect investors' perceptions of the riskiness of the asset. Policies that lower required rates of 
return will reduce financing costs. The following model deconstructs the securitization process revealing the specific roles played by three PV-related uncertainties on the market valuation of a proffered solar ABS.

\section{Model}

Measurement of the cost of financial capital raised through securitization begins with cash flow analysis. The solar developer's, or originator's, cash flows depend on the performance of its PPAs. The originator can hold these contracts for their duration, ensuring a long-term annual income stream, or it can sell PPAs to a special purpose entity (SPE) to raise immediate capital. The difference between the discounted value of the cash flows to the originator and the sale price of the PPAs determines the PV developer's cost of capital (Stone and Zissu, 2005; Fabozzi, 2012).

\subsection{Value of Discounted Cash Flow - Originator}

Begin by assuming a solar developer originates $m_{0}$ number of PPAs. For simplicity, assume these contracts are identical, are originated simultaneously, and have a 20-year lifespan (Cory, 2009). The rights and obligations specified by the PPAs establish an anticipated value for contracted receivables in the third-party ownership structure. Though these contracts are complex, for modeling purposes they can be simplified to a few essential components: i) amount of electricity contracted, ii) unit price of electricity, and iii) recovery procedures in the case of contract termination.

Under the PPA, the consumer pays the system owner for $100 \%$ of the electricity produced by the installed PV system. At the time of installation, all systems are capable of producing an annual output of $e_{0} \mathrm{kWh}$ of electricity per year. Small system degradation causes this value to decline over the life of the contract. Therefore, annual energy output [kWh] can be rewritten:

$$
e_{t}=(1-\alpha)^{t-1} e_{0}
$$

where $\alpha$ is a constant annual degradation rate and $t$ is the number of years. The system operates at full capacity during its first year of operation.

Contract default is the primary source of cash flow uncertainty, and impacts revenues by reducing the total energy output under contract. Liability will fall on the consumer if early termination is the result of consumer bankruptcy, sale of home, or purposeful termination by the consumer in response to changes in technology or energy costs (Rahus, 2008; CARICOM, 2012; FUTUREGEN, 2012). Under the standardized residential PPA produced by SAPC, defaulting consumers are liable for all unpaid balances, the cost of returning the system, and all costs incurred by the owner in recovery (SAPC, 2013). The stringency of these default remedies should reduce frivolous payment avoidance, but it will not stop default in cases where the consumer is unable to pay. Under these circumstances, full, timely recovery of payments due is highly unlikely. 
Given the uncertainty of the timing, and success of recovery procedures, liability payments are not included in assessed cash flows. Instead, for simplicity, a recovery rate of zero is assumed (KBR, 2012). When a contract fails, the stream of associated payments is terminated, and it is removed from the asset pool. Contracts fail at an annual rate of $\beta$. Actual termination rates will reflect system owner characteristics, economic conditions, and energy market conditions. Though these vary over time, for simplicity the contract termination rate is assumed to be constant over the life of the ABS. The total number of contracts at time $t$ is given by:

$$
m_{t}=(1-\beta)^{t-1} \cdot m_{0}
$$

where $m_{o}$ is the number of contracts included in pool initially. All contracts are assumed to be active during their first year. Based on equations (1) and (2), the annual amount of energy under contract by the pooled PPAs is equal to:

$$
E_{t}=\left[(1-\alpha)^{t-1} e_{0}\right] \times\left[(1-\beta)^{t-1} m_{0}\right]
$$

Electricity prices are the final determinant of cash flows. A single price, $p_{0}$, is applied to all contracts. This price increases by a constant annual escalation rate of $\gamma$, making the $\$ / \mathrm{kWh}$ price of electricity in any given period:

$$
p_{t}=(1+\gamma)^{t-1} p_{0}
$$

Using equations (3) and (4), annual cash flows are given by

$$
c_{t}=p_{t} \times E_{t}=\left[(1+\gamma)^{t-1} p_{0}\right] \times\left[(1-\alpha)^{t-1} e_{0}\right] \times\left[(1-\beta)^{t-1} m_{0}\right]
$$

The total real value of the contracts to the originator is:

$$
C=\sum_{1}^{20}\left(c_{t} /(1+\delta)^{t}\right)
$$

where $\delta$ is the risk-free discount rate.

\subsection{Valuation of Discounted Cash Flow - Investor}

Figure 1 illustrates the relationships between the entities involved in securitization by providing a brief description of their rights and responsibilities. 


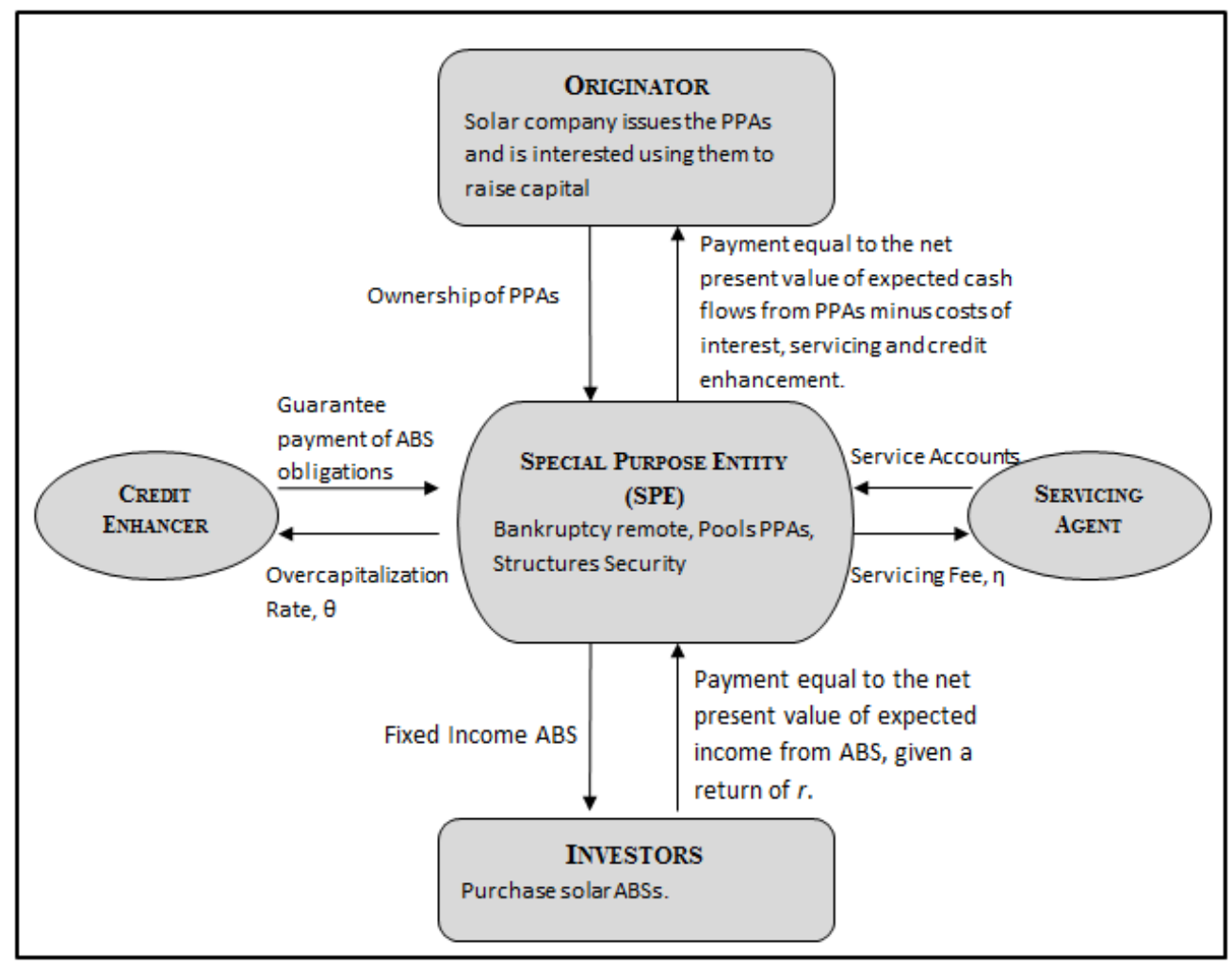

Figure 1: Process of Securitization

As shown in Figure 1, each entity involved in the securitization process requires payment (Stone and Zissu, 2005). Credit enhancement is the first cost incorporated into the model. To achieve the high credit rating required for an investment grade asset, credit enhancement is used to offset the riskiness of underlying assets (Fabozzi, 2007). While there are many potential forms of credit enhancement, overcollateralization is used in this analysis. Under this method, the par value of issued securities is lower than the value of the collateral (Fabozzi, 2004) - the more overcollateralization required, the less capital can be raised from the asset pool.

Let $\theta$ be the amount of overcollateralization required. $\theta$ is the percent of contracts set aside each year to cover potential contract defaults. It is assumed that overcollateralization is always sufficient to ensure payment of investor obligations. However, credit rating agencies are not always correct in predicting actual default rates. Therefore, if $\theta$ is the amount of overcollateralization required, the difference between this value and the actual rate of early contract termination ( $\beta$ ) will be: $\sigma=\theta-\beta \geq 0$,

where $\sigma$ is excess overcollateralization. Separation of overcollateralization into its required and its excess components allows closer consideration of both the impacts of responsible contract issuance and accurate risk evaluation by credit rating agencies on the cost of securitization. 
Credit enhancement is incorporated in the model in a manner similar to $\beta . c_{t}^{s}$, the annual cash flows included in the securitization, are given by equation (7), where the number of contracts is influenced by $\theta=\beta+\sigma$.

$$
c_{t}^{s}=p_{t} \times E_{t}=\left[(1+\gamma)^{t-1} p_{0}\right] \times\left[(1-\alpha)^{t-1} e_{0}\right] \times\left[(1-(\beta+\sigma))^{t-1} m_{0}\right]
$$

Next, servicing fees are deducted from cash flows (Wishnia, 2010). Let the servicing fee be a percentage of annual revenues, $\eta$, so that the annual fee paid to the servicing agent, $F_{t}$, is given by

$$
F_{t}=\eta \times c_{t}^{s}
$$

This value is subtracted from annual cash flows.

Finally, the cost of investor return is incorporated in the cash flow analysis. In equation (6), cash flows are discounted at $\delta$, the risk-free level. Investors require a higher rate of return as compensation for risk. If that risk premium is given by $\mu$, then the rate of return to the solar ABS is $r=\delta+\mu$.

When investor returns are accounted for, the present value of the income stream generated by the PPAs included in the securitization pool is given by:

$$
C_{A B S}=\sum_{1}^{20}\left[\frac{(1-\eta) \cdot c_{t}^{s}}{(1+r)^{t}}\right]
$$

Because $C_{A B S}$ must be sufficient to cover all ABS payment obligations, it must be true that the present value of expected cash flows from the underlying collateral net all securitization costs is equal to the present value of the income stream from the ABS. Consequently, this value is also equal to the market price of the securities (Zhang, 2011; Coval et al., 2009).

\subsection{Cost of Capital}

Internal rate of return (IRR) is used to assess the originator's cost of capital. This technique calculates the interest rate that brings a series of cash flows to a net present value of zero. IRR is calculated as:

$$
0=C_{A B S}-\sum_{t=1}^{20} \frac{c_{t}}{(1+I R R)^{t}}+\frac{\sum_{1}^{20}\left[c_{t}-c_{t}^{s}\right]}{(1+I R R)^{20}}
$$

Reflected in the equation is the receipt of payment for issued securities in the initial period, $t=0$. This is a positive value equal to $C_{A B S}$. In return for immediate access to capital, the originator foregoes the stream of cash flows $\mathrm{c}_{t}$, over the subsequent 20 years. The cost of foregone cash flows is offset in the final period by the reimbursement of any excess funds from credit enhancement. Overcollateralization generates excess funds when the actual default rate is less than the expected default rate, $\theta>\beta$. Any interest earned 
on this accumulated capital is kept by the servicing agent, while the remainder returns to the originator when all obligations are met. Funds in this account are equal to the sum of nominal net cash flows in each time period.

\section{Results}

There are three points in the securitization process that are of particular interest: 1) the formation of the asset pool, 2) the process of asset evaluation, and 3) the purchase of the asset by uncertain investors. To assess the extent to which a securitization's outcome is influenced by these moments, three variables are analyzed - the rate of early contract termination, $\beta$; excess overcollateralization required by rating agencies, $\sigma$; and the rate of return required by investors, $r$. The model is parameterized and all other variables are assigned fixed values. $\beta, \sigma$, and $r$ are each assigned a range of possible values and a sensitivity analysis is performed. Values are listed in Table 1.

Table 1: Values of Variables Included in Base Case

\begin{tabular}{|c|c|c|c|}
\hline Variable & Definition & Units & Value \\
\hline$m_{o}$ & $\begin{array}{l}\text { Number of contracts included } \\
\text { in pool }\end{array}$ & Thousands & 100 \\
\hline $\mathrm{e}_{0}$ & $\begin{array}{l}\text { Initial annual electricity } \\
\text { output of installed PV system }\end{array}$ & kWh/year & $\begin{array}{l}\text { 11,000 (EIA, } \\
2012)\end{array}$ \\
\hline$\alpha$ & PV system degradation rate & \%/year & $\begin{array}{l}0.5 \text { (Chianese, et } \\
\text { al., 2003; Jordan, } \\
\text { 2011; Realini, } \\
\text { 2003; Va'zquez, } \\
\text { 2008) }\end{array}$ \\
\hline$\gamma$ & Price escalation rate & \%/year & $\begin{array}{l}2 \text { (Akins, 2009; } \\
\text { EIA, 2012b; } \\
\text { Shah, 2011) }\end{array}$ \\
\hline$P$ & Initial price of electricity & $\$ / \mathrm{kWh}$ & 0.10 (EIA, 2012a) \\
\hline$\delta$ & Zero coupon treasury rate & $\%$ & $\begin{array}{l}2 \text { (Wall Street } \\
\text { Journal, 2013) }\end{array}$ \\
\hline$\eta$ & Servicing Fee & $\%$ & 1 (Furletti, 2002) \\
\hline$r$ & Investor return & $\%$ & 6 through 12 \\
\hline$\beta$ & $\begin{array}{l}\text { Rate of early contract } \\
\text { termination }\end{array}$ & \%/year & $\begin{array}{l}0,1,3,5,7,10, \\
15\end{array}$ \\
\hline$\sigma$ & $\begin{array}{l}\text { Difference between actual and } \\
\text { expected rate of early } \\
\text { termination }\end{array}$ & \%/year & 0 through 8 \\
\hline
\end{tabular}

$\beta$ is appraised over a range of values from 0 to 15 percent per year. This range is quite broad due to significant uncertainty regarding rates of early contract termination. In the nascent market for home-based solar PV systems there is only about five years of data on contract defaults for 
residential PPAs (Colmer, 2013). Incorporation of several options allows the impact of changes in the actual default rate on the cost of capital to be studied.

A similar range is used to evaluate $\sigma$. The value of this variable depends on the confidence of credit rating agencies in their ability to accurately predict the rate of early contract termination. It should be noted here that the technical risk associated with PV technology itself is small, as there are well-documented decades of performance data throughout the world to draw on for predicting solar electricity generation rates and levelized cost calculations (Branker, Pathak and Pearce, 2011). However, early contract termination data is not as readily available. Give the absence of historical data, their limited technical familiarity, and their narrow industry experience, raters are expected to be quite uncertain. Uncertainty increases the perceived riskiness of the underlying assets, resulting in higher rates of overcollateralization. In this analysis $\sigma$ is limited to 16 percent per year in order focus on values at which securitization is a viable alternative. It is anticipated that risk assessment accuracy would increase with experience.

To evaluate the importance of $r$, the rate of investor returns, values between 6 and 12 percent are included in the analysis. In order to attract investors, solar ABS must promise a rate of return sufficient to compensate for the time value of money and the risk associated with the investment product. The lower bound for these rates is based on return targets expressed by mutual fund, retail investor, and pension fund managers during interviews conducted by Bloomberg New Energy Finance (BNEF, 2012). As the estimated cost of equity financing, $12 \%$ is the rate at which securitization ceases to be attractive (Bolinger, 2009; Minzt, 2010; US PREF, 2011). It is therefore selected as an upper limit on the rate of return.

\subsection{Cost of Securitization, IRR}

Table 2 presents specific values for IRR based on different combinations of $\sigma, \beta$, and $r$. Using $12 \%$ as the approximate cost of tax equity financing, Table 1 demonstrates that for many reasonably anticipated combinations of $\beta, \sigma$, and $r$ securitization will reduce financing costs. Variable combinations that meet this cost reducing criteria are shaded. Given the variable ranges specified, $6.12 \%$ is the lowest potential cost of financing calculated. 
Table 2: Cost of Financing Solar Projects Using Securitization, based on different combinations of $\beta, \sigma$, and $r$.

\begin{tabular}{|c|c|c|c|c|c|c|c|c|c|c|}
\hline & \multicolumn{9}{|c|}{ Rate of Early Contract Termination $(\beta)=0$} \\
\hline & & \multicolumn{9}{|c|}{ Credit Enhancement (\% above default rate) } \\
\hline & & 0 & 1 & 2 & 3 & 4 & 5 & 6 & 7 & 8 \\
\hline \multirow{6}{*}{ 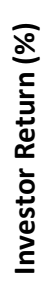 } & 6 & 6.12 & 6.45 & 6.85 & 7.34 & 7.91 & 8.59 & 9.37 & 10.25 & 11.22 \\
\hline & 7 & 7.12 & 7.50 & 7.95 & 8.49 & 9.12 & 9.84 & 10.66 & 11.56 & 12.55 \\
\hline & 8 & 8.13 & 8.55 & 9.05 & 9.63 & 10.30 & 11.07 & 11.91 & 12.84 & 13.83 \\
\hline & 9 & 9.13 & 9.60 & 10.14 & 10.76 & 11.48 & 12.27 & 13.14 & 14.08 & 15.08 \\
\hline & 10 & 10.14 & 10.64 & 11.22 & 11.89 & 12.63 & 13.45 & 14.35 & 15.30 & 16.31 \\
\hline & 11 & 11.15 & 11.69 & 12.31 & 13.00 & 13.78 & 14.62 & 15.53 & 16.50 & 17.51 \\
\hline
\end{tabular}

Rate of Early Contract Termination $(\beta)=1$

\begin{tabular}{|c|c|c|c|c|c|c|c|c|c|c|}
\hline & \multicolumn{9}{|c|}{ ate of Early Contract Iermınation $(\beta)=1$} \\
\hline & & \multicolumn{9}{|c|}{ Credit Enhancement (\% above default rate) } \\
\hline & & 0 & 1 & 2 & 3 & 4 & 5 & 6 & 7 & 8 \\
\hline \multirow{6}{*}{ 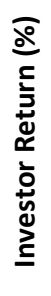 } & 6 & 6.12 & 6.47 & 6.88 & 7.38 & 7.98 & 8.67 & 9.47 & 10.37 & 11.35 \\
\hline & 7 & 7.13 & 7.52 & 7.98 & 8.54 & 9.18 & 9.92 & 10.76 & 11.67 & 12.67 \\
\hline & 8 & 8.13 & 8.57 & 9.08 & 9.68 & 10.37 & 11.15 & 12.01 & 12.95 & 13.95 \\
\hline & 9 & 9.14 & 9.62 & 10.17 & 10.81 & 11.54 & 12.35 & 13.23 & 14.19 & 15.19 \\
\hline & 10 & 10.15 & 10.66 & 11.26 & 11.94 & 12.70 & 13.53 & 14.44 & 15.40 & 16.41 \\
\hline & 11 & 11.15 & 11.71 & 12.34 & 13.05 & 13.84 & 14.70 & 15.62 & 16.59 & 17.61 \\
\hline
\end{tabular}

Rate of Early Contract Termination $(\beta)=3$

\begin{tabular}{|c|c|c|c|c|c|c|c|c|c|c|}
\hline & \multicolumn{9}{|c|}{ Rate of Early Contract Termination $(\beta)=3$} \\
\hline & & \multicolumn{9}{|c|}{ Credit Enhancement (\% above default rate) } \\
\hline & & 0 & 1 & 2 & 3 & 4 & 5 & 6 & 7 & 8 \\
\hline \multirow{6}{*}{ 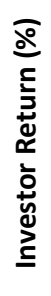 } & 6 & 6.13 & 6.50 & 6.94 & 7.47 & 8.10 & 8.84 & 9.67 & 10.59 & 11.59 \\
\hline & 7 & 7.14 & 7.55 & 8.05 & 8.63 & 9.31 & 10.08 & 10.95 & 11.89 & 12.90 \\
\hline & 8 & 8.14 & 8.61 & 9.15 & 9.78 & 10.50 & 11.31 & 12.19 & 13.15 & 14.17 \\
\hline & 9 & 9.15 & 9.65 & 10.24 & 10.91 & 11.67 & 12.50 & 13.41 & 14.38 & 15.40 \\
\hline & 10 & 10.16 & 10.70 & 11.33 & 12.04 & 12.82 & 13.68 & 14.61 & 15.59 & 16.61 \\
\hline & 11 & 11.16 & 11.75 & 12.41 & 13.15 & 13.96 & 14.84 & 15.78 & 16.77 & 17.79 \\
\hline
\end{tabular}

Rate of Early Contract Termination $(\beta)=5$

\begin{tabular}{|c|c|c|c|c|c|c|c|c|c|c|}
\hline & & & & & & & & & \\
\hline & & \multicolumn{9}{|c|}{ Credit Enhancement (\% above default rate) } \\
\hline & & 0 & 1 & 2 & 3 & 4 & 5 & 6 & 7 & 8 \\
\hline \multirow{6}{*}{ 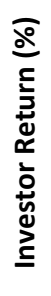 } & 6 & 6.14 & 6.53 & 7.01 & 7.57 & 8.23 & 8.99 & 9.86 & 10.80 & 11.82 \\
\hline & 7 & 7.15 & 7.59 & 8.11 & 8.73 & 9.44 & 10.24 & 11.13 & 12.09 & 13.12 \\
\hline & 8 & 8.16 & 8.64 & 9.22 & 9.88 & 10.62 & 11.46 & 12.37 & 13.34 & 14.37 \\
\hline & 9 & 9.16 & 9.69 & 10.31 & 11.01 & 11.79 & 12.65 & 13.58 & 14.56 & 15.59 \\
\hline & 10 & 10.17 & 10.74 & 11.40 & 12.13 & 12.94 & 13.82 & 14.77 & 15.76 & 16.79 \\
\hline & 11 & 11.18 & 11.79 & 12.48 & 13.24 & 14.08 & 14.98 & 15.93 & 16.93 & 17.96 \\
\hline
\end{tabular}

Rate of Early Contract Termination $(\beta)=7$

\begin{tabular}{|c|c|c|c|c|c|c|c|c|c|c|}
\hline & \multicolumn{9}{|c|}{ Rate of Early Contract Termination $(\beta)=7$} \\
\hline & & \multicolumn{9}{|c|}{ Credit Enhancement (\% above default rate) } \\
\hline & & 0 & 1 & 2 & 3 & 4 & 5 & 6 & 7 & 8 \\
\hline \multirow{3}{*}{ 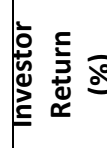 } & 6 & 6.15 & 6.57 & 7.07 & 7.66 & 8.36 & 9.15 & 10.04 & 11.00 & 12.04 \\
\hline & 7 & 7.16 & 7.63 & 8.18 & 8.83 & 9.56 & 10.39 & 11.30 & 12.28 & 13.32 \\
\hline & 8 & 8.17 & 8.68 & 9.28 & 9.97 & 10.75 & 11.60 & 12.53 & 13.52 & 14.56 \\
\hline
\end{tabular}




\begin{tabular}{|l|l|l|l|l|l|l|l|l|l|}
\hline 9 & 9.18 & 9.73 & 10.38 & 11.10 & 11.91 & 12.79 & 13.74 & 14.73 & 15.77 \\
\hline 10 & 10.18 & 10.78 & 11.46 & 12.22 & 13.06 & 13.96 & 14.91 & 15.92 & 16.95 \\
\hline 11 & 11.19 & 11.83 & 12.54 & 13.33 & 14.19 & 15.11 & 16.07 & 17.08 & 18.12 \\
\hline
\end{tabular}

Rate of Early Contract Termination $(\beta)=10$

\begin{tabular}{|c|c|c|c|c|c|c|c|c|c|c|}
\hline & & & 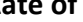 & Ty & 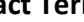 & Tativin & & & \\
\hline & & \multicolumn{9}{|c|}{ Credit Enhancement (\% above default rate) } \\
\hline & & 0 & 1 & 2 & 3 & 4 & 5 & 6 & 7 & 8 \\
\hline \multirow{6}{*}{ 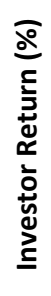 } & 6 & 6.17 & 6.63 & 7.17 & 7.80 & 8.54 & 9.37 & 10.29 & 11.28 & 12.33 \\
\hline & 7 & 7.18 & 7.69 & 8.28 & 8.97 & 9.84 & 10.60 & 11.54 & 12.54 & 13.59 \\
\hline & 8 & 8.19 & 8.74 & 9.38 & 10.11 & 10.92 & 11.81 & 12.76 & 13.76 & 14.81 \\
\hline & 9 & 9.20 & 9.80 & 10.48 & 11.24 & 12.08 & 12.99 & 13.95 & 14.96 & 16.00 \\
\hline & 10 & 10.21 & 10.84 & 11.56 & 12.36 & 13.22 & 14.14 & 15.12 & 16.13 & 17.17 \\
\hline & 11 & 11.21 & 11.89 & 12.64 & 13.46 & 14.34 & 15.28 & 16.26 & 17.28 & 18.32 \\
\hline
\end{tabular}

Rate of Early Contract Termination $(\beta)=15$

\begin{tabular}{|c|c|c|c|c|c|c|c|c|c|c|}
\hline & \multicolumn{9}{|c|}{ 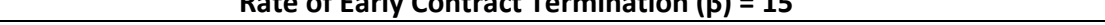 } \\
\hline & & \multicolumn{9}{|c|}{ Credit Enhancement (\% above default rate) } \\
\hline & & 0 & 1 & 2 & 3 & 4 & 5 & 6 & 7 & 8 \\
\hline \multirow{6}{*}{ 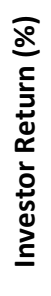 } & 6 & 6.21 & 6.72 & 7.32 & 8.02 & 8.81 & 9.69 & 10.65 & 11.67 & 12.73 \\
\hline & 7 & 7.22 & 7.78 & 8.44 & 9.18 & 10.01 & 10.91 & 11.88 & 12.90 & 13.95 \\
\hline & 8 & 8.23 & 8.84 & 9.54 & 10.32 & 11.18 & 12.10 & 13.08 & 14.10 & 15.15 \\
\hline & 9 & 9.24 & 9.89 & 10.63 & 11.44 & 12.32 & 13.26 & 14.25 & 15.27 & 16.32 \\
\hline & 10 & 10.25 & 10.94 & 11.71 & 12.55 & 13.45 & 14.40 & 15.39 & 16.41 & 17.46 \\
\hline & 11 & 11.26 & 11.99 & 12.79 & 13.65 & 14.56 & 15.52 & 16.52 & 17.54 & 18.59 \\
\hline
\end{tabular}

\subsection{Rate of Early Contract Termination, $\beta$ and the Performance of Securitization}

When adequate credit enhancement is assumed, $\beta$ is far more relevant to the ability to raise capital, than it is to the cost of capital. Values presented in Table 2 show that increases in $\beta$ cause only a very limited decrease in the number of potential cost reducing combinations of $\sigma$ and $r$, and have little impact on the cost of financing. For example, if $\sigma$ and $r$ are equal to 0 and 6 percent respectively, a 5 percent increase in $\beta$ from 10 to 15 percent increases IRR by only 0.04 percent. This negligible effect is a result of the use of foregone cash flows, rather than potential cash flows, in the determination of costs (Bragg, 2012). Because the default rate is the same whether contracts are held for their duration, or securitized, the loss of cash flow is not attributable to securitization and impacts cost mainly through interaction with $\sigma$. 


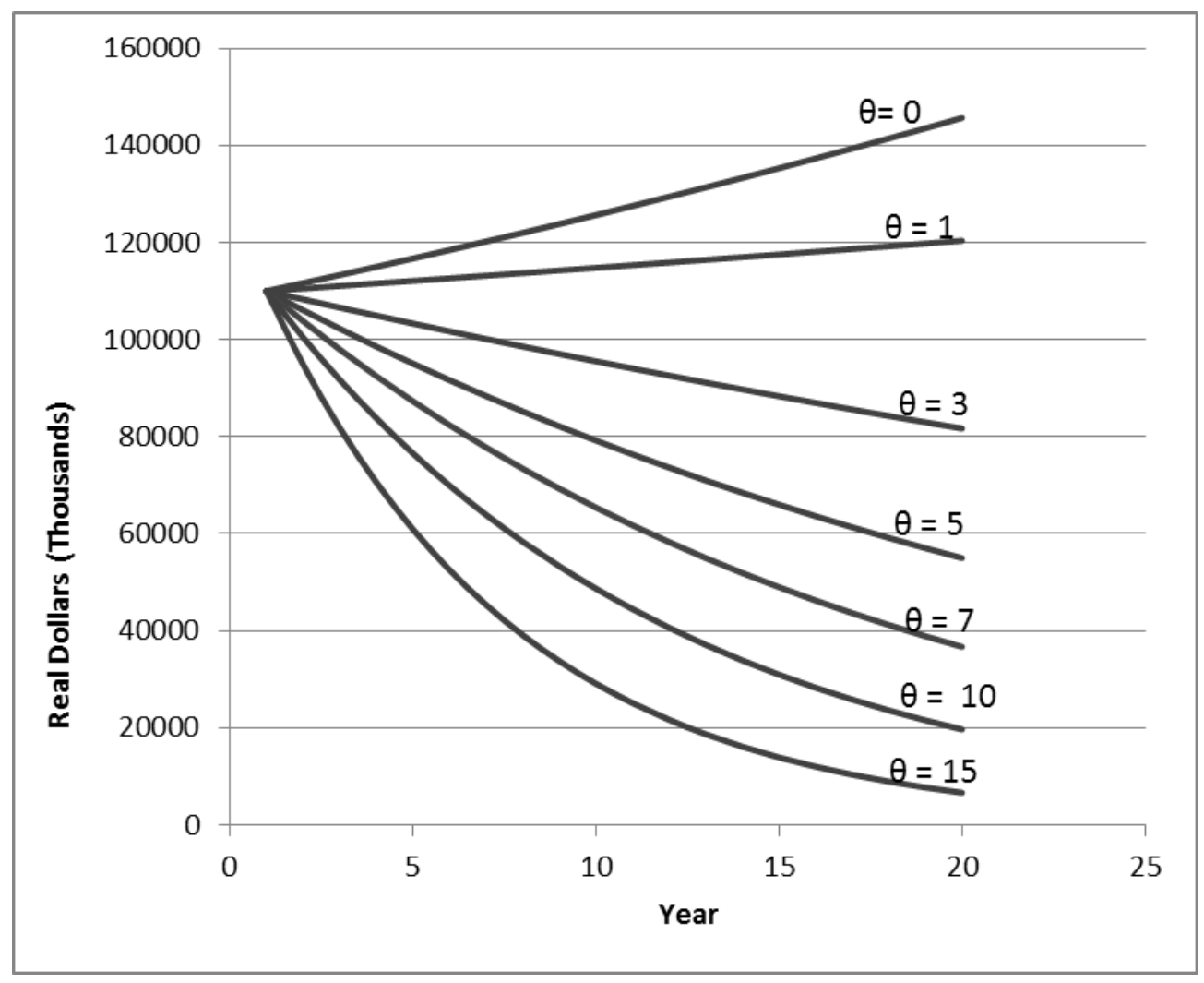

Figure 2: Cash Flows from Asset Pool, given different Rates of Overcollateralization $(\boldsymbol{\theta}=\boldsymbol{\beta}+\boldsymbol{\sigma})$

However, securitization can also be evaluated by its ability to raise capital from a given pool of PPAs. $\beta$ is critical in determining the price of solar ABS. By eliminating cash flows from the asset pool, early contract termination reduces the value of the assets and lowers the potential market value of the securities. This effect is compounded when additional cash flows are diverted due to excess overcollateralization. Required credit enhancement, $\theta$, depends on the combined value of $\beta$ and $\sigma$. Figure 2 shows the nominal value of annual cash flows generated by the pool of assets under different assumptions about $\theta$. Though receipts in year 1 are the same under all values, these payments quickly diverge resulting in disparate cash flow profiles.

The impact of these alternative cash flow profiles on the value of a proffered security is depicted in Figure 3. The higher $\theta$, the less capital can be raised from the pooled PPAs. However, changes in $\theta$ have a larger impact on security prices when $\theta$ is low than when $\theta$ is high. Consequently, there is a benefit to improving the quality of even high-quality asset pools. For example, when $r$ is $6 \%$, by reducing $\theta$ from $4 \%$ to $3 \%$, the originator can raise an additional $\$ 77.6$ million. The value of the same $1 \%$ decrease in $\theta$ is $\$ 107.2$ million when $\theta$ is reduced from $1 \%$ to $0 \%$. 


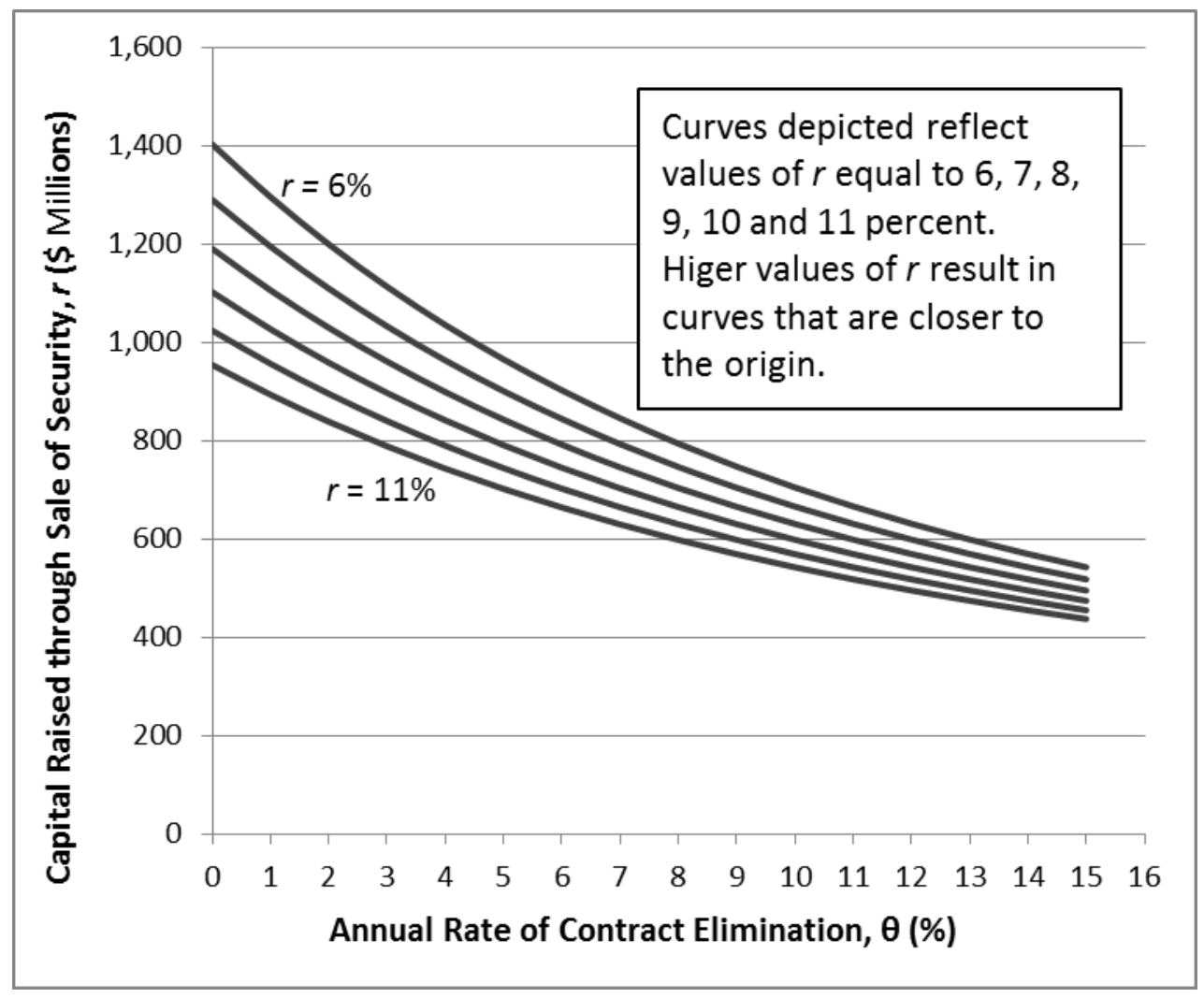

Figure 3: Impact of Overcollateralization on Security Price at different Rates of Investor Return.

\subsection{Rate of Excess Overcollateralization, $\sigma$, and the Performance of Securitization}

Inaccurate risk assessment reduces the performance of securitization by both increasing financing costs and reducing security prices. Figure 4 depicts the impact of changes in $\sigma$ on the cost of financing at different levels of $\beta$. The graph shows that rater inaccuracy always increases financing costs. Additionally, it demonstrates that incremental cost increases are progressively larger as the degree of accuracy declines. An increase in $\sigma$ from 0 to 1 percent adds 0.34 percent to IRR, while a similar change from 7 to 8 percent increases IRR by 0.98 percent $(\beta=0, r=6)$. 


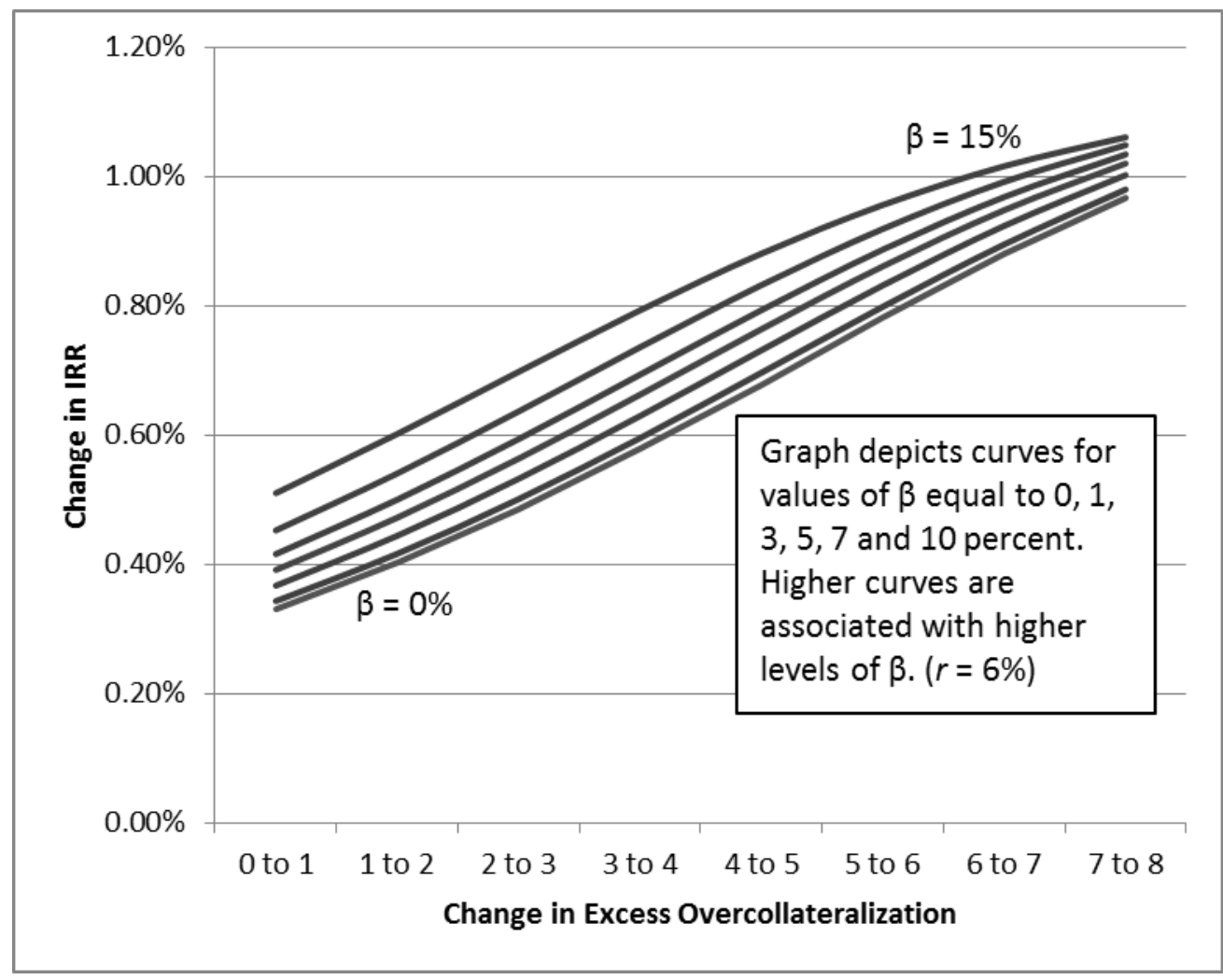

Figure 4: Impact of Increases in Excess Overcollateralization on IRR

Rater inaccuracy is also more costly when the quality of the asset pool is low. As $\beta$ increases, a larger portion of future cash flows are eliminated, rather than set aside to cover potential losses, as they are for increases in $\sigma$. Income accumulated as a result of this set-aside is returned to the originator when all obligations have been settled. At higher levels of $\beta$, total cash flows are lower; meaning the cost of setting aside the stream of income required by $\sigma$ is more costly.

Excess overcollateralization has the same impact on security prices as the rate of contract default. Assuming that require overcollateralization is always adequate, these both affect the security's price by adding to the total overcollateralization demand by the rating agency. Figure 3 illustrates how security prices decline as credit enhancement costs increase.

\subsection{Rate of Investor Return, $r$, and the Performance of Securitization}

While the rate of investor return influences both the cost of financing and the price of the security, its clearest and most significant impact is felt in the cost of financing. If both $\beta$ and $\sigma$ are set equal to zero, then IRR differs only slightly from $r$. In Table 2, when $r=6$, then IRR $=6.12$, and when $r=$ 11 , IRR $=11.15$. IRR increases by approximately $1.01 \%$ as $r$ increases by $1 \%$. There is also an important interaction between $\sigma$ and $r$. At higher levels of $\sigma$, changes in $r$ result in increasingly large changes in IRR. Because $\sigma$ measures the inaccuracy of credit rating agencies, this result shows part of 
the cost of imperfect information. Excess overcollateralization magnifies the impact of increases in $r$, swelling the rate of increase in the IRR.

When investors require higher rates of return, the amount of capital that can be raised based on a particular asset pool is reduced. The size of this effect is influenced by $\theta$. Changes in $r$ have a larger impact on price when $\theta$ is low, than when $\theta$ is high. In Figure 3, when $\theta=15 \%$, raising $r$ from $6 \%$ to $11 \%$ reduces the security price by 106 million, or by $19.5 \%$. When $\theta=0 \%$, the same change in $r$ reduces price by $\$ 402$ million, or 31\%. As a result, the relative importance of $\theta$ and $r$ in determining security prices depends on the level of $\theta$. When $\theta$ exceeds $11 \%$, the security price benefit of reducing $\theta$ exceeds the benefit of a similar percentage reduction in $r$. For values of $\theta$ below $11 \%$, greater price benefits can be achieved by reducing $r$.

\section{Policy Implications}

In revealing how changes in the values of $\beta, \sigma$, and $r$ influence the success of securitization, the model provides targets for policy intervention to facilitate the development of an efficient market for securitized solar assets. These policies are organized according to the point at which they impact the securitization process. This helps clarify the policy's intended goal as it relates to the model's results

\subsection{Formation of the Asset Pool and the Rate of Early Contract Termination, $\beta$}

The investigation of the role of asset formation, as measured by the rate of early policy termination, reveals two outcomes. First, when the originator is responsible for providing adequate credit enhancement, changes in the quality of the asset pool have little impact on the cost of financing. Instead, the benefit of reducing $\beta$ comes nearly entirely from the ability to raise more capital from a given pool of assets. This implies that solar developers have a strong incentive to implement and adhere to strict credit evaluation procedures when issuing PPAs. With little need to use legal authority to compel participation or compliance, policies to enhance this process could be promulgated by a trade organization or an independent industry representative.

\subsubsection{Standardization}

In 2013, the Solar Access to Public Capital (SAPC) working group released three standard contract templates (NREL, 2013). They represent the work of more than 120 member organizations, and are the culmination of the widely recognized need for standardization of contracts and contracting procedures (Colmer, 2011; Hu, 2012; NREL, 2013). There are two ways in which the widespread adoption of a standardized contract would benefit solar developers by facilitating the creation of high quality asset pools (reducing $\beta$ ). First, creating a solar ABS market of efficient size necessitates the pooling of assets across firms. Such pooling requires that contracts and contracting procedures be standardized. Investors are looking for minimum 
transaction sizes of $\$ 100$ - \$200 million (Joshi, 2012), and prefer issuance of over \$350 million (Nelson et al., 2013). Despite rapid growth in the residential third-party ownership market, no individual firm currently owns sufficient PPAs to accomplish an issuance of this size (Colmer, 2013). Also, there are a large number of smaller solar developers who could benefit from the type of pooling possible with contract standardization. These developers have had difficulty finding financing because investors are not generally interested in projects of less than $\$ 30$ million (Di Capua, et al. 2011), leaving projects of 5MW or less without an effective small-scale financing structure that can efficiently generate returns for all parties involved (Miller, 2012).

Next, standardization simplifies data collection and analysis. Such data collection is necessary given the short history and evolving use of thirdparty ownership in residential solar (S\&P, 2012). Standardization would streamline the pooling of data to increase observation points, and expand diversity within the sample, improving the potential for statistical analysis. For developers, data analysis could provide feedback that would improve credit screening and contracting procedures.

Data collected by the Connecticut (CT) Solar Lease Program provides a glimpse of the potential value of establishing a larger database to track asset performance. The CT Solar Lease Program, launched in 2008 as a publicprivate partnership, provided 855 leases to homeowners throughout the state (Speer, 2012). The performance of those leases was tracked, creating a longitudinal database that includes socioeconomic data on the lessees, paired with their payment activity (Speer, 2012). If expanded to include a broader, more diverse set of assets, this sort of data could be used develop credit evaluation tools and standards. A national effort to collect and analyze this data could draw from the example of two organizations, the Open Solar Peformance and Reliability Clearinghouse (O-SPaRC) and the truSolar working group. In 2013 O-SPaRC launched a national database for tracking the performance of solar installations (NREL, 2013) following early work in Canada to provide open access to data to assist the PV industry develop (Buitenhuis and Pearce, 2012; Pearce, Babasola and Andrews, 2012). Data collection relies on the self-interest of industry members to motivate participation (Montgomery, 2013). A similar structure could be developed to collect performance information. In another effort, truSolar, an industry consortium, is working to establish a system for sharing asset performance data within the commercial and industrial solar segment (truSolar, 2013). Firms in the residential sector of the market could follow this example, establishing an independent organization to collect and analyze applicable data or work with established organizations like NREL.

As an important component in the process of pooling and information production, firms are unlikely to need inducement to adopt standardized contracts. Model estimation suggests that by aggregating assets to issue solar ABS a firm can reduce their financing cost by between 5 and 13 percent. Results also indicate that when the quality of the asset pool is improved, reducing the default rate by $1 \%$, the capital raised by the issuance can increase by $6 \%$. These potential gains provide firms with substantial incentive to adopt standardization. 


\subsubsection{Geographic Diversification}

Though there has been rapid growth in the use of third-party financing for residential solar, much of that growth is located in the state of California (Joshi, 2012; SEIA, 2013). Geographic concentration of this sort exposes the asset pool to the risk of significant increases in default rates in response to a natural or manmade disaster, decline of regional industry, or change in state policy related to solar. This risk creates a clear mandate for national expansion. However, state policy variations make this change difficult.

Differences in state policy impede expansion of residential PV in several ways. States have different laws governing utility contracts that restrict allowable activity (Kwan, 2012). For example, there are only 22 states (plus D.C. and Puerto Rico) that allow the use of third-party PPA's (DSIRE, 2013). State to state differences also limit market expansion by increasing the legal and analytical expertise required for market participation (Burns and Kang, 2012). This drives up costs, and reduces developer interest (Mendelsohn, 2012). Additionally, in many locations there is a perceived lack of policy commitment. Changes in policy can undermine a project's financial viability making developers wary of investing (Nelson and Peirpont, 2013). Taken together, these problems led Paul Durbin, a renewable energy attorney to state, “... when it comes to renewable energy development there are only a handful of states where you can get it done..." (Lussenburg et al., 2011).

It will take the application of significant time and resources to improve this situation. Unlike solar developers, states do not necessarily have strong incentives to adjust their policies in ways that benefit the solar power industry. Despite widespread support in the public for distributed solar energy (e.g. more than 90\% want greater reliance on solar) (Greenberg, 2009), policies and procedures in most states still favor conventional centralized electricity generation and distribution. Inter-state coordination would benefit from federal inducement, but in the current political environment this sort of intervention is unlikely without significant political change. Rather, it is continual pressure by interested developers that appears clear to motivate gradual change, reinforcing the growing strength of a maturing industry.

\subsection{Asset Evaluation and the Rate of Excess Overcollateralization, $\sigma$.}

Usually a rating agency would use historical data to forecast asset default rates (Fabozzi, 2008; Hu, 2011). This data is not available for residential PV PPAs. Instead, raters are looking for appropriate proxy data, and are considering the use of utility or mortgage default rates (KBR, 2012). While similar, these do not capture industry specific risks like technological improvement, or home sale (Colmer, 2013). This reduces the accuracy of the risk assessment, increases the amount of credit enhancement required, and hinders the performance of securitization. 
Two approaches can be used to address this problem. First, the industry can improve its data collection and sharing efforts. As discussed, this can be facilitated by standardization. The model demonstrates that by improving the accuracy of the risk assessment the cost of securitized financing decreases. With contracts lasting 20 years or more, acquisition of data will be a long process. The alternative is to reduce the burden of excess overcollateralization by establishing a public entity to insure the assets, reducing the originator's cost of credit enhancement.

\subsubsection{Credit Enhancement}

Securitized assets use credit enhancement to attain investment grade ratings. After the financial crisis of 2008, with the collapse of the mortgage backed securities market, the cost of credit enhancement increased. Before 2007 , clean investments could get a AAA rating with around $7 \%$ credit enhancement. In 2011, the required rate was over 25\% (Herve-Mignucci, et al., 2013). When incorporated into the model, this rate produces an IRR that exceeds the viable level. Government supported loan guarantees or insurance could reduce financing costs by lowering the amount of credit enhancement required from solar developers (Nelson and Peirpont, 2013). This would be similar, although to a lesser degree and lower risk than the insurance backing provided to the nuclear energy industry (Zelenika-Zovko and Pearce, 2011).

Federal credit enhancement has played a role in the development of several industries. By providing a "first loss" reserve, the government guarantees, partially or in full, the liabilities of a project towards its lenders (Frisari et al., 2013; Mendelsohn and Feldman, 2013). This has been done by both the Federal Housing Administration (FHA) - mortgage guarantees, and the Small Business Administration - business loans guarantees (Sanders et al., 2013). It was also used by the Department of Energy in 2005 to help bring innovative, clean energy technologies to market through its 1703 Loan Guarantee Program (ACORE, 2013).

A similar type of insurance could be developed to support the access of renewable energy firms to public capital. By replacing existing tax credits, which incur a dollar-for-dollar loss, with a federal insurance program, it is possible for the federal government to both reduce costs and utilize leverage to expand solar funding (ASR, 2008). However, introduction of insurance would change the model and alter results related to the formation of asset quality. By relieving firms of the responsibility for covering default related losses, moral hazard is introduced and the incentive for firms to maintain high quality asset pools is reduced (Herve-Mignucci et al., 2013).

\subsection{Purchase of solar ABS and the Investor Rate of Return, $r$.}

As the primary determinant of financing costs, actions to reduce the required rate of investor return will directly improve the performance of solar securitization. In the model, it is assumed that credit enhancement is sufficient to attain an investment grade rating. If this is true, the principle problem in recruiting investors is the lack of liquidity of solar ABS. 
Unlisted, non-standard securities that are not actively traded in any market will require a liquidity premium, and will generally not be purchased by institutional portfolio managers (Frisari et al., 2013).

\subsubsection{Liquidity}

Achieving sufficient scale will create liquidity, increase demand for solar ABS, and reduce the cost of securitized financing. In 2011, it was estimated that securitization of all residential and commercial rooftop contracts could generate $\$ 733$ million in bonds (Borod, 2013). Market growth since that time would add considerably to this total. However, securitizing many of these contracts would be difficult given their tax equity structure.

When tax equity finance is used solar developers must typically offer investors $15-40 \%$ of ITC benefits, MACRS benefits, and a share of the project's future cash distributions (Colmer, 2011;Marks, 2012; US PREF, 2011). This share can be $90 \%$ - 99\% of a project's initial cash flow (S\&P, 2011). Tax benefits are taken over the first several years of the project during the recapture period (Joshi, 2012). During this time, the financer must be recognized as the owner of the asset and the producer of electricity (Hechimovich and Stevens, 2012). If the sale of a PPA to a SPE for the purpose of securitization interferes with this ownership claim, tax benefits are lost (ASR, 2008; Hintze, 2013). Assets can be securitized after the recapture period, but this can be five or more years into the project, and can do little to relieve immediate liquidity concerns. It is possible to utilize securitization before the end of this recapture period, by attaining loans backed by developers' equity positions. These loans could then be aggregated (Lowder, 2013). Even with this option, liquidity cannot be added quickly. However, continued market expansion provides the promise of long-term relief.

\section{Conclusions}

Securitization of solar leases and PPAs has the potential to raise significant capital, while reducing project financing costs well below the cost of alternative financing. Realization of this potential can be facilitated by policy action to target key points in the securitization process - the formation of the asset pool, the process of asset evaluation, and in the purchase of the asset by uncertain investors. Results indicate that actions taken at each of these points can affect the cost and efficacy of a securitization. Using appropriate policy to target each of these moments, the efficiency of the process can be improved and associated input costs reduced. Though addressing the problems identified will be challenging, with access to the vast financial resources of institutional investors as the incentive there is significant impetus for making necessary policy changes to expand the deployment of PV technology. 


\section{Acknowledgements}

The authors would like to thank M. Islam for helpful discussions.

\section{References}

ACORE, 2013. Strategies to Scale-Up U.S. Renewable Energy Investment. American Council on Renewable Energy. Available at: http://www.acore.org/images/uploads/Strategies-to-Scale-Up-US-Renewable-EnergyInvestment.pdf?utm_source=SilverpopMailing\&utm_medium=email\&utm_campaign=ACO RE\%20Releases\%20New\%20Study\%20Highlighting\%20Key\%20Strategies\%20to\%20Scale -Up\%20U.S.\%20Renewable\%20Energy\%20Investment\%20\%281\%29\&utm_content=.

Akins, S., 2009. Drafting and Negotiating the Optimal Power Purchase Agreement. California Center for Sustainable Energy. Available at: $<$ http://www.slideshare.net/ccsemedia/drafting-and-negotiating-the-optimal-power-purchaseagreement>.

ASR., 2008. The Sprint for Independence. Asset Securitization Report, October, Structured Finance News.

Barbose, G., Darghouth, N., Weaver, S., Wiser, R., 2013. Tracking the Sun VI: An Historical Summary of the Installed Price of Photovoltaics in the United States from 1998 to 2013. US Department of Energy, Lawrence Berkley National Laboratory, LBNL-6350E.

BNEF, 2012. Re-imagining US Solar Financing. US Solar - White Paper, Bloomberg New Energy Finance. Available at: $<$ http://www.scsrenewables.com/scsimages/BNEF\%20Reimagining\%20US\%20Solar\%20Financing.pdf > .

Bolinger, M., Wiser, R., Cory, K., James, T., 2009. PTC, ITC or Cash Grant? An Analysis of the Choice Facing Renewable Power Projects in the United States. Lawrence Berkeley National Laboratory, LBNL-1642E. Berkley, CA.

Bolinger, M., 2009. Financing Non-Residential Photovoltaic Projects: Options and Implications. Lawrence Berkeley National Laboratory, LBNL-1410E, Berkley, CA. $<$ http://eetd.lbl.gov/ea/ems/reports/lbnl-1410e.pdf $>$.

Borod, R., 2013. The Devil in the Details of Solar Securitization. Practical International Corporate Finance Strategies, 39(7).

Bragg, S., 2012. Business Ratios and Formulas: A Comprehensive Guide. John Wiley and Sons, Hoboken, NJ.

Branker, K., Pearce, J.M., 2010. Financial Return for Government Support of Large-Scale Thin-Film Solar Photovoltaic Manufacturing in Canada. Energy Policy, 38, pp. 4291-4303.

Branker, K., M.J.M. Pathak, J.M. Pearce, 2011a. A Review of Solar Photovoltaic Levelized Cost of Electricity. Renewable and Sustainable Energy Reviews, 15, 4470-4482

Branker, K., Shackles, E., Pearce, J.M., 2011b. Peer-to-Peer Financing Mechanisms to Accelerate Renewable Energy Deployment. The Journal of Sustainable Finance \& Investment, 1(2), 138-155.

Burns, J., Kang, J., 2012. Comparative Economic Analysis of Supporting Policies for Residential Solar PV in the United States: Solar Renewable Energy Credit Potential. Energy Policy, 44(May), pp. 217-225.

CARICOM. 2012. Power Purchase Agreement Template. Caribbean Community Secretariat. Available at:

$<$ www.caricom.org/jsp/.../power_purchase_agreement_template.doc>.

Chianese, D., Realini, A., Cereghetti, N., Rezzonico, S., Bura, E., Friesen, G., 2003. Analysis of weather c-Si PV modules. Proceedings of 3rd world conference on photovoltaic solar energy conversion, p. 5. 
Colmer, N., 2011. Solar ABS: The Next Esoteric Niche. Asset Securitization Report, (Oct).

Colmer, N., 2013. When Will Solar ABS Finally Catch Fire? Asset Securitization Report, (May), pp. 20-21, 30.

Coval, J., Jurek, J., Stafford, E. 2009. The Economics of Structured Finance. Journal of Economic Perspectives, 23(1), pp. 3-25.

Cory, K., Canavan, B., Koenig, R., 2009. Power Purchase Agreement Checklist for State and Local Governments. National Renewable Energy Laboratory, Golden, CO.

Di Capua, Michel, Amy Grace and Dipa Sharif., 2011. The Return - and Returns of Tax Equity for US Renewable Projects. Bloomberg New Energy Finance, November. Available at: <http://www.newenergyfinance.com/WhitePapers/download/54>.

DSIRE, 2013. $3^{\text {rd }}$ Party Solar PV Power Agreements. U.S. Department of Energy. Available at: <http://www.dsireusa.org/documents/summarymaps/3rd_Party_PPA_map.pdf >

Energy Information Administration, 2005. Policies to Promote Non-Hydro Renewable Energy in the United States and Selected Countries. Available at: $<$ http://www.eia.doe.gov/fuelrenewable.html>.

EIA, 2012a. Table 5A - Residential Average Monthly Bill, by Census Division and State, 2011. Energy Information Administration. Available at: <http://www.eia.gov/electricity/sales_revenue_price/pdf/table5_a.pdf >

EIA, 2012b. Renewable Energy Generation and Generating Capacity, Reference Case. Annual Energy Outlook 2012. Energy Information Administration.

EIA, 2012c., Electric Power Monthly, U.S. Energy Information Administration.

Fabozzi, F. L., 2007. Fixed Income Analysis, $2^{\text {nd }}$ Edition. Wiley \& Sons, Hoboken, NJ

Fabozzi, F. L., Kothari, V., 2008. Introduction to Securitization. John Wiley and Sons, Hoboken, NJ.

Fan, G.Z., Sing, T. F., Ong, S. E., Sirmans, C.F., 2004. Governance and optimal financing for asset-backed securitization. Journal of Property Investment and Finance, (22(5)), pp.414- 434.

Frisari, G., Herve-Mignucci, M., Micale, V., Mazza, F., 2013. Risk Gaps: A Map of Risk Mitigation Instruments of Clean Investment. Climate Policy Initiative. Available at: http://climatepolicyinitiative.org/wp-content/uploads/2013/01/Risk-Gaps-A-Map-of-RiskMitigation-Instruments-for-Clean-Investments.pdf.

Furletti, M., 2002. An Overview of Credit Card Asset-Backed Securities. Discussion Paper, Federal Reserve Bank of Philadelphia. Available at: < http://www.philadelphiafed.org/consumer-credit-and-payments/payment-cardscenter/events/workshops/2002/creditcardsecuritization_012002.pdf > .

FUTUREGEN Industrial Alliance, Inc., 2012. Unit Contingent Power Purchase Agreement. Available at: <http://www2.illinois.gov/ipa/Documents/FutureGen-AlliancePower-Purchase-Agreement.pdf $>$.

Herndon, A., 2012. First Solar Bonds Financing \$4.6 Billion U.S. Panel Boom. Bloomberg News, July 28.

Herve-Mignucci, M., Frisari, G., Micale, V., Mazza, F., 2013. Risk Gaps: First-Loss Protection Mechanisms. Climate Policy Initiative. Available at: http://climatepolicyinitiative.org/wp-content/uploads/2013/01/Risk-Gaps-First-LossProtection-Mechanisms.pdf.

Hintze, J., 2013. First Solar Deals, Likely Private, Face Tax Equity Hurdles. Asset Securitization Report, August, pp. 16-17. Singapore.

Hu, J., 2011. Asset Securitization: Theory and Practice. John Wiley and Sons, 
IREC, 2012. U.S. Solar Market Trends 2011. Interstate Renewable Energy Council, Available at: < $\underline{\text { http://www.irecusa.org/wp-content/uploads/IRECSolarMarketTrends-2012- }}$ Web-8-28-12.pdf $>$.

Jaffrey, J., 2012. Changing the US financing landscape for restarting stalled and future solar PV projects. PV Magazine. Available at: < http://www.pvmagazine.com/opinion-analysis/blogdetails/beitrag/changing-the-us-financing-landscape-forrestarting-stalled-and-future-solar-pv-projects $>$.

Jordan, D.C., Smith, R.M., Osterwald, C.R., Gelak, E., Kurtz, R.S. 2011. Outdoor PV Degredation Comparison. National Renewable Energy Laboratory, Conference Paper NREL/CP-5200-47704.

Joshi, J., 2012. Renewable Energy Finance and Securitization. The Journal of Structured Finance, (Winter), pp. 174-183.

Joshi, J., Scott, C., Griffin, A., McDermitt, M., King, T., Davis, T., 2012. Renewable Energy ABS Sector Review. American Securitization Forum. Available at: $<$ http://www.americansecuritization.com/uploadedFiles/Renewable_Energy_ABS_Sector_R eview_1_25 11AM_PB3_v3.pdf $>$.

KBR, 2012. Evaluation Credit Risks in Solar Securitizations. Kroll Bond Ratings. Available at: < https://www.krollbondratings.com/show_report/265>.

Kwan, C., 2012. Influence of local environmental, social, economic and political variables on the spatial distribution of residential solar PV arrays across the United States. Energy Policy, 47(August), pp. 332-344.

Lowder, T., 2013. How Could Debt Fit with Tax Equity in the Solar Financial Landscape? Part II. NREL. Available at: https://financere.nrel.gov/finance/content/howcould-securitization-debt-fit-tax-equity-solar-financial-landscape-pt-ii.

Lussenburg, S., Barrett, M, Durbin, P., 2011. Finding the Money: Securing Capital for Energy Innovation. Canada-United States Law Journal, 36(2), p. 277-07.

Marks, Allan. 2012, Renewable Energy Financing Mechanisms: What Can We Expect?. Renewable Energy World, (February). Available at: <http://www.renewableenergyworld.com/rea/news/article/2012/02/renewable-energyfinancingmechanisms-and-incentives-what-can-we-expect>.

Mendelsohn, M., 2012. How Do We Lower Solar Installation Costs and Open the Market to Securitized Portfolios: Standardization and Harmonization. Renewable Energy Project Finance. Available at: https://financere.nrel.gov/finance/content/how-do-we-lowersolar-installation-costs-and-open-market-securitized-portfolios-standardize-.

Mendelsohn, M.; Harper, J. June 2012. §1603 Treasury Grant Expiration: Industry Insight on Financing and Market Implications. NREL Report No. TP-6A20-53720

Mendelsohn, M., Krycik, C., Bird, L., Schwabe, P., Cory, K., 2012. The Impact of Financial Structure on the Cost of Solar Energy. National Renewable Energy Laboratory, Technical Report NREL/TP-6A20-53086.

Mendelsohn, M., Feldman, D., 2013. Financing U.S. Renewable Energy Projects Through Public Capital Vehicles: Qualitative and Quantitative Benefits. National Renewable Energy Laboratory, Technical Report NREL/TP-6A20-58315.

Miller, I. R. 2012. Barriers to Tax Equity Syndication for Solar Development. American Council on Renewable Energy. Available at: < http://www.acore.org/wpcontent/uploads/2012/07/Tax-Equity-Barriers.IanMiller.InternSpring2012.pdf >.

Mintz, Levin, Cohen, Ferris, Glovsky, Popeo., 2010. Renewable Energy Project Finance in the U.S.: An Overview and Midterm Outlook. Available at: $<$ http://www.greentechmedia.com/images/wysiwyg/reports/MintzLevin-WP-Web-Final1(2).pdf $>$.

Montgomery, J., 2013. Bundling Solar Performance Data to Give Investors TLC. Renewable Energy World.com. Available at: 
<http://www.renewableenergyworld.com/rea/news/article/2013/04/building-a-solardatabase-to-give-investors-tlc?cmpid=SolarNL-Tuesday-April16-2013>.

Nelson, D., Peirpoint, B., 2013. The Challenge of Institutional Investment in Renewable Energy. Climate Policy Initiative. Available at: http://climatepolicyinitiative.org/wp-content/uploads/2013/03/The-Challenge-ofInstitutional-Investment-in-Renewable-Energy.pdf.

NREL, 2013a. The Open PV Project. National Renewable Energy Lab. Available at: https://openpv.nrel.gov/.

NREL, 2013b. Solar Securitization and Public Finance Capital. National Renewable Energy Lab. Available at: https://financere.nrel.gov/finance/solar_securitization_public_capital_finance.

Parkinson, Glen, 2013. Groundbreaking solar financing to lead to cheaper installations. Reneweconomy. Available at: http://reneweconomy.com.au/2013/groundbreaking-solar-financing-to-lead-to-cheaperinstallations-88239.

Pearce J.M., 2002. Photovoltaics - a path to sustainable futures. Futures, 34(7), pp. 663-674(12).

Pietruszko, S.M., 2006. Feed-In Tariff: The Most Successful Support Programe Photovoltaic Energy Conversion, Conference Record of the 2006 IEEE 4th World Conference, pp.2524 - 2527.

Prindle, B., Eldridge, M., Eckhardt, M., Frederick, A., 2007. The Twin Pillars of Sustainable Energy: Synergies between Energy Efficiency and Renewable Energy Technology and Policy. American Council for an Energy-Efficient Economy. Report number : E074.

Rahus Institute, 2008. The Customer’s Guide to Solar Power Purchase Agreements. Available at: <http://www.californiasolarcenter.org/sppa.html $>$.

Realini A., 2003. MTBF - PVm, mean time before failure of photovoltaic modules, final report. p. $1-58$.

S\&P, 2012. Will Securitization Help Fuel the U.S. Solar Power Industry. Standard \& Poor's Financial Services LLC. Available at: $<$ http://www.cleanenergyfinancecenter.org/wpcontent/uploads/WillSecuritizationHelpFuelTheUSSolarPowerIndustry_Jan2012_tsrcopy.pdf>.

S\&P, 2013. Credit Ratings Definitions and FAQs. Available at: http://www.standardandpoors.com/ratings/definitions-and-faqs/en/us\#def_4.

SAPC, 2013. Zero Down Residential Lease Contract (Aggregated Business Model Version). Available at: https://financere.nrel.gov/finance/solar_securitization_public_capital_finance.

Sanders, R., Milford, L., Rittner, T., 2013. Reduce Risk, Increase Clean Energy: How States and Cities ar Using Old Finance Tools to Scale Up a New Industry. Clean Energy and Bond Finance Initiative. Available at: http://kresge.org/sites/default/files/CleanEnergy-Group-Reduce-Risk-Increase-Clean-Energy.pdf.

Schwabe, P., Mendelsohn, M., Mormann, F., Arent, D., 2012. Mobilizing Public Markets to Finance Renewable Energy Projects: Insights from Expert Stakeholders. National Renewable Energy Laboratory, Technical Report NREL/TP-6A20-55021.

SEIA. 2011. U.S. Solar Market Insight: Year-in-Review-2010. Solar Energy Industries Association, Washington, D.C.

SEIA, 2013. Solar Energy Facts: Q2 2013. Solar Energy Industries Association, Washington, D.C. Available at: http://www.seia.org/sites/default/files/Q2\%202013\%20SMI\%20Fact\%20Sheetv2.pdf. 
Shah, C., 2011. Power Purchase Agreements. U.S. Department of Energy, Federal Emergency Management Program. Available at:

$<$ http://www1.eere.energy.gov/femp/pdfs/afo_ppa_pres.pdf >.

Available at:

Solar Industry, 2013. U.S. Surpasses 10 GW Mark In Installed Solar PV Capacity. http://www.solarindustrymag.com/e107_plugins/content/content.php?content.12940.

Stone, C., Zissu, A., 2005. The Securitization Markets Handbook: Structures and Dynamics of Mortgage-and Asset-Backed Securites. Bloomberg Press, NY.

Talavera, D. L., Nofuentes, G., Aguilera, J., 2010. The internal rate of return of photovoltaic grid-connected systems: A comprehensive sensitivity analysis. Renewable Energy, 35(1), 101-111.

Timilsina, G.R., Kurdgelashvili, L., Narbel, P.A., 2012. Solar energy: Markets, economics and policies. Renewable and Sustainable Energy Reviews 16, 449-465.

October 23

Trabish, H. 2012. Talking Solar Securitization with Centrosolar. Green Tech Media.

$\operatorname{truSolar}^{\mathrm{TM}}$. 2013. FAQ. Available at: http://www.trusolarscore.com/faq/.

U.S. Partnership for Renewable Energy Finance. 2011. Tax Equity Market Observations. Available at: <http://uspref.org/wp-content/uploads/2011/07/US-PREF-ITCGrant-Market-Observations-12.1.2011-v2.pdf $>$.

Va'zquez, M., Rey-Stolle, I., 2008. Photovoltaic Module Reliability Model Based on Field Degradation Studies. Progress in Photovoltaics: Research and Application, Wiley InterScience 16, 419-433.

Wall Street Journal. 2013. Market Data Center - U.S. Treasury Strips. January 11. $<$ http://online.wsj.com/mdc/public/page/2_3020-tstrips.html >.

Wilkins, G., 2002. Technology Transfer for Renewable Energy: Overcoming Barriers in Developing Countries, 1st editionThe Royal Institute of International Affairs, UK.

Wishnia, J., 2010. Servicing of Residential Mortgage Loans in Securitization Transactions. New Jersey Lawyer Magazine, Oct.(266). Available at: $<$ http://www.lowenstein.com/files/Publication/d259d81a-c7c7-4e92-ac878ae883ca1f51/Presentation/PublicationAttachment/1e3f57f9-9b58-44a2-81888c0dfdcd5f8a/Servicing\%20of\%20Residential\%20Mortgage\%20Loans\%20in\%20Securitizat ion\%20Transactions.pdf>.

Zhang, Ke Zheng, 2012. The Risk-Isolating Paradox in China’s Asset Securitization. University of Macau. 